\title{
REVIEW
}

\section{Population connectivity among migratory and stationary cod Gadus morhua in the Northeast Atlantic - A review of 80 years of study}

\author{
Jarle Tryti Nordeide ${ }^{1, *}$, Steinar D. Johansen ${ }^{1,2}$, Tor Erik Jørgensen ${ }^{1}$, \\ Bård Ove Karlsen ${ }^{1,2}$, Truls Moum ${ }^{1}$
}

${ }^{1}$ Marine Genomics Research Group, Faculty of Biosciences and Aquaculture, University of Nordland, 8049 Bodø, Norway

${ }^{2}$ Department of Medical Biology, Faculty of Health Sciences, University of Tromsø, 9037 Tromsø, Norway

\begin{abstract}
The population structure of Atlantic cod Gadus morhua L. in the Barents Sea and in fjords and coastal waters in Norway and northwestern Russia has been a controversial subject since the 1930s. Eight decades of scientific inquiry have compared migratory NE Arctic (NA) and stationary Norwegian and Russian coastal cod (NC). At one extreme the existence of 2 non-interbreeding groups is advocated, whereas others find support for low genetic differentiation due to substantial gene flow, with geographical distance being the limiting factor. We review studies of a wide range of phenotypic (e.g. growth, maturation, counts of vertebrae) and polymorphic genetic markers (e.g. allozymes, mtDNA, microsatellites, single nucleotide polymorphisms). Regardless of whether or not the observed differences have a genetic basis, $70 \%$ of the 54 reviewed papers conclude that NA and NC differ with respect to the characters studied. However, few papers remain after exclusion of those relying on characteristics or markers that are generally agreed to be subject to selection and therefore less suited to assessing population connectivity. The lack of studies examining the potential influence of environments on growth of annual zones in otoliths is surprising, since otoliths are used to categorize specimens in managing the NA and NC and in scientific papers. We conclude that it is still an open question whether NA and NC effectively make up 1 large population or $>1$ non-interbreeding 'groups'. As next-generation sequencing technology transforms 'population genetics' into 'population genomics', we will move towards a better understanding of differentiation among fish populations.
\end{abstract}

KEY WORDS: Cod · Population genetics $\cdot$ Gadus morhua $\cdot$ NE Atlantic $\cdot$ Selection $\cdot$ Non-neutral loci

\section{INTRODUCTION}

The cod Gadus morhua fisheries in Norwegian waters have traditionally been and still are economically important. In 2009, 30000 tonnes of cod at a value of 11 billion NOK (approximately $£ 1$ billion) were captured, and cod was the economically most valuable fish species according to Statistics Norway (www.ssb.no). Norwegian quotas of migrating and stationary cod (see below) in northern Norway are managed as a single unit (Aglen 2010).
The population structure of cod in the NE Atlantic Ocean and the Barents Sea has been a subject of controversy since Rollefsen $(1933,1934 \mathrm{a}, \mathrm{b})$ reported 2 groups of cod based on the pattern of the annual growth zones of their otoliths. Cod in the Barents Sea, on the one hand, and in fjords and coastal regions of northern Norway and NW Russia (Fig. 1), on the other hand, are categorized as NE Arctic cod (NA) and Norwegian coastal cod (NC), respectively. The terms 'stock' and 'population' are both used to describe NA and NC in the literature. We avoid the term 'stock' in 


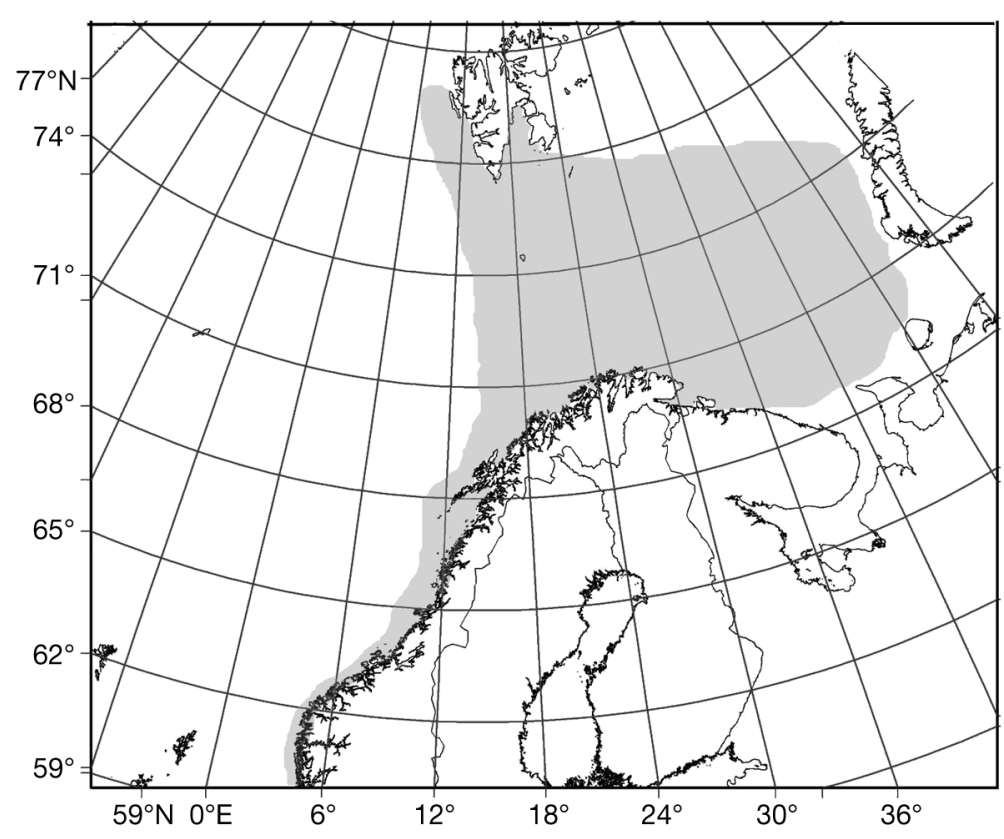

Fig. 1. Gadus morhua. Map showing the approximate distribution (shaded area) of Atlantic cod in the Barents Sea and along the Norwegian and northwest Russian coast. The shaded area was redrawn from Fig. 1 in Sundby (2000)

this review (though it appears in Tables $1 \& 2$ where we cite other papers), because it may signify anything from a coherent unit in a population-genetic sense to a group of fish that is fished upon at a given location and time. NA migrate from feeding areas in the Barents Sea and near Svalbard to spawning areas along the coast of North Norway, and return after spawning (Fig. 1) (Bergstad et al. 1987, Brander 1994). The spawning ground off the Lofoten Islands in North Norway is the main spawning area of NA, where 65 to $75 \%$ of the eggs are produced (Brander 1994, Sundby \& Nakken 2008). Most eggs and larvae drift northwards along the coast into the Barents Sea, whereas a minor portion of the NA seem to settle and inhabit deep waters in the outer coastal areas of northern Norway (Løken et al. 1994, Nordeide \& Pettersen 1998, Westgaard \& Fevolden 2007) (Fig. 1). NC inhabit coastal areas and fjords, migrate short distances and spawn along most parts of the Norwegian coast (Rollefsen 1954, Jakobsen 1987), including the Lofoten Islands (Hylen 1964, Møller 1966, 1968, Nordeide 1998). In fact, ripe individuals of both NC and NA are found in the same catches at the spawning grounds off Lofoten (Nordeide 1998). Most cod spawn from March to early May (Kjesbu 1989), with peak spawning of NA around April 1 (Pedersen 1984). Cod mating behaviour is poorly known, although cod is suggested to have a lekking mate system, including active mate choice (Hutchings et al. 1999, Nordeide \& Folstad 2000). Sug- gested cues used to select among mates are sound and dance (Brawn 1961a,b,c, Engen \& Folstad 1999, Nordeide \& Kjellsby 1999, Rowe \& Hutchings 2003, Skjæraasen et al. 2006, Rowe et al. 2008). Behavioural differences between NA and NC during spawning have not been demonstrated.

On the one hand, the existence of noninterbreeding sibling species of cod has been advocated (Møller 1969). Others claim that there is very low genetic differentiation between groups of cod, including NA and $\mathrm{NC}$, due to gene flow with geographical distance being the limiting factor (e.g. Mork et al. 1985). The controversy remains unresolved. Since the first studies of otolith patterns in the 1930s, a number of characteristics have been studied in cod from northern Norway, seeking to understand its population structuring. These characteristics include body growth, sexual maturation, body shape (K-factor), number of vertebrae, allozymes and isozymes, blood types, haemoglobin, and DNA polymorphisms of the nuclear and mitochondrial genomes (for references see Table 1). In addition to the pioneering work on otoliths by Rollefsen (1933), the discovery of some genetic markers with significant differences in frequency between NA and NC, especially haemoglobin (Møller 1966) and Pan I (Fevolden \& Pogson 1995), created enthusiasm and nourished a number of studies on cod in the NE Atlantic (see Table 1). Descriptive field studies have dominated, although some field and laboratory experiments have been carried out as well. Several of these genetic markers were later claimed to be subject to selection ('non-neutral') and therefore to be less useful in studies of connectivity between NA and NC (see Table 2, and text below).

There are specific problems associated with the estimation of population genetic parameters in marine species, due to their large population sizes (and concomitant low levels of genetic drift) and a low signal to noise ratio for high gene flow species (Waples 1998, Palsbøll et al. 2007). However, the study of genetics of populations is currently making tremendous steps forward. While population genetic studies so far typically have examined $\leq 10$ genetic markers, recent breakthroughs will enable next-generation sequencing technology to map and compare entire genomes within weeks (Mardis 2008a,b, Hohenlohe et al. 2010). This prospect of 'population genomics' based on SNP analyses will significantly improve our ability to detect the genetic signal and promises a better knowledge of the genetics of marine populations within the next few 
years (Nielsen et al. 2009b). The new tools are now being introduced in the study of cod populations (Johansen et al. 2009), and large-scale cod sequence ventures are in progress at both sides of the Atlantic Ocean (Nielsen et al. 2009b). However, there will still be significant impediments to overcome, e.g. in the ascertainment of single nucleotide polymorphisms (SNPs) and the fundamental problem that populationlevel demographic processes and selection are confounded (Nielsen 2005).

The introduction of next-generation sequencing techniques in studies of population genetics is anticipated to occur at least partly at the expense of some of the currently applied methods in population genetics of cod. The time is therefore right to review what we have learnt during the nearly $80 \mathrm{yr}$ since the publication of Rollefsen (1933). The aims of the current review are to: (1) present 2 hypotheses to explain the observed connectivity of NA and NC, (2) give an overview of empirical studies on the connectivity between NA and NC and show which characteristics and genetic markers have revealed differences between the 2 groups of cod, (3) show which studies are left after removing those using characteristics and genetic markers claimed to be subject to selection.

\section{SIGNATURES OF POPULATION DIFFERENTIATION AND INCIPIENT SPECIATION}

Population differentiation is inversely related to gene flow and is the first step towards reproductive isolation under several models of speciation. High gene flow due to absent or weak physical barriers in the ocean is one obvious factor which reduces local adaptations and slows down or impedes differentiation and speciation processes in marine species; large population sizes is another (e.g. Palumbi 1994, Ryman et al. 1995). Selection, being a vital force in the shaping of population structures, will target particular loci that respond to different selective regimes in groups of individuals inhabiting different environments. Thus, loci targeted by selection in different directions are the first to differ in allele frequency during a speciation event. The amount of divergence at selected loci will be determined by the relative strengths or direction of the selection in the 2 environments, and by migration. On the other hand, 'neutral' loci are those where selective forces are not currently favouring some alleles relative to others. Thus, neutral loci will be the more informative on gene flow and genetic drift, i.e. on demographic processes and population subdivisions. It follows that management decisions should not be based on non-neutral markers solely (e.g. O'Leary et al. 2007, Beebee \& Rowe 2008, but see Ferguson 1994).
Moreover, the lack of detectable differences at neutral loci should not be taken as sufficient evidence to draw conclusions about population connectivity, whereas the opposite, namely the presence of differences at neutral loci, would indicate population divergence (Ryman et al. 1995, Lowe \& Allendorf 2010). We should also keep in mind that population genetic evidence is relevant, but not necessarily decisive by itself when it comes to delineation of management units (Waples 1998, Waples \& Gaggiotti 2006).

Two alternative hypotheses on population connectivity and corresponding allele frequencies at neutral and non-neutral loci in Gadus morhua NA and NC juveniles and spawning individuals are illustrated in Fig. 2. According to the 'divergent selection hypothesis', the NA and NC spawners may interbreed at their common spawning grounds (Fig. 2A). The frequency of nonneutral alleles at a given locus could still differ significantly between NA and NC due to de novo selection on a generational basis if certain alleles have a selective advantage in 'coastal environments', whereas alternative alleles are selected in 'Barents Sea environments'. In contrast, the frequency of neutral alleles (alleles at another locus not subject to selection) would not be expected to differ between specimens at the coast (NC) and in the Barents Sea (NA), since spawners from both groups interbreed. Several of the loci and characteristics coded by loci used in population genetic studies in North Atlantic cod seem to be 'non-neutral' (see Table 2, text below). Strong selection may act differently at some of these non-neutral loci in cohorts settling in different (e.g. warm and cold) environments, whereas individuals from both environments return and mix genes at the same spawning grounds. It follows from the 'divergent selection hypothesis' that non-neutral alleles affected by de novo selection should be revealed by comparing frequencies of observed and Hardy-Weinberg expected genotypes within each sample. The empirical studies (see Table 1) give little support for such a deviation. However, the statistical power of such tests is low and often unable to reveal deviation with the number of cod typically examined in a sample (e.g. Wallace 1958, Lewontin \& Cockerham 1959, Wentzel-Larsen \& Nordeide 2001, Salanti et al. 2005). Nielsen et al. (2009b) considered such 'divergent selection' as a 'not unrealistic' explanation for the observed differences in selected loci and markers in species with high fecundity and high mortality at early life stages, like the cod.

The 'historical isolation hypothesis' provides an alternative scenario for the connectivity between NA and NC (Fig. 2B). This hypothesis assumes a current lack of interbreeding between NA and NC, persisting for some time back in history, even though sexually mature specimens may (currently) occupy the same 
A

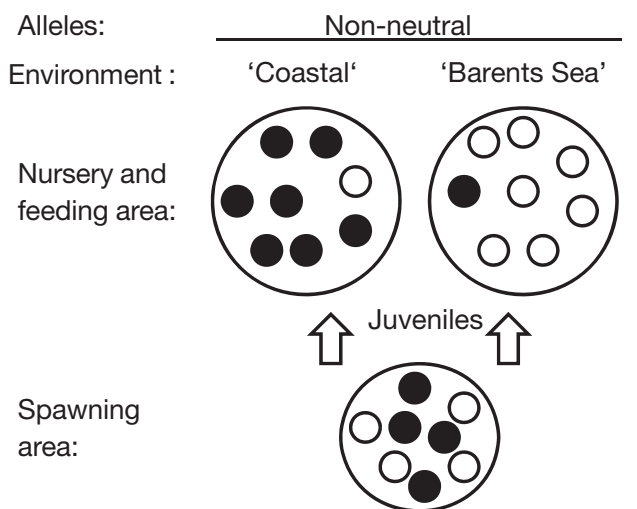

Interbreeding adults

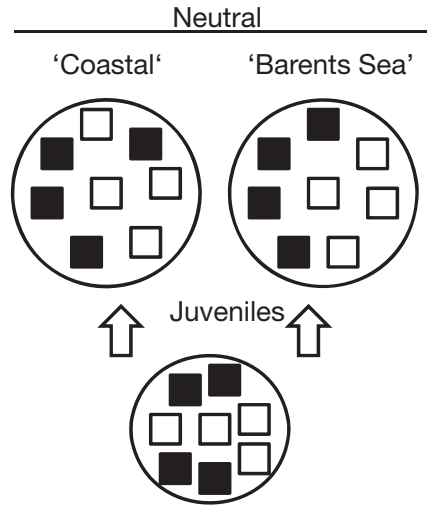

Interbreeding adults
B

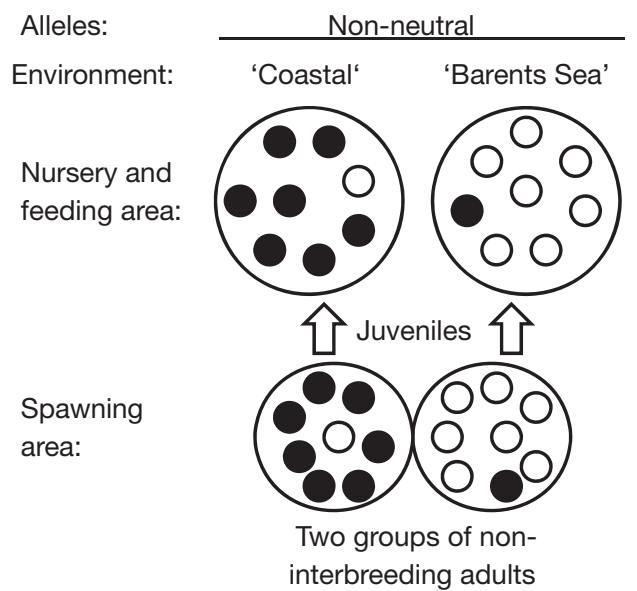

'HISTORICAL ISOLATION HYPOTHESIS'

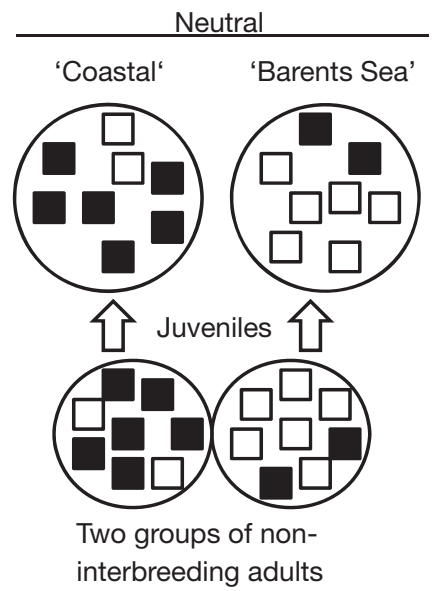

Allele with a selective advantage in 'coastal environments'

Allele with a selective advantage in 'Barents Sea environments'

Two neutral alleles at a particular locus
Fig. 2. Gadus morhua. Simplified depiction of 2 alternative hypotheses to explain the present allelic distribution at non-neutral and neutral genetic loci in cod off North Norway. (A) The 'divergent selection hypothesis' assumes ongoing interbreeding of NA (Barents Sea cod) and NC (coastal cod) and de novo directional selection on each juvenile year class. (B) The 'historical isolation hypothesis' assumes a history of complete or partial isolation of NA and NC breeding units. In this case, differentiation would affect both neutral and nonneutral loci due to genetic drift and founder effects in either group, while the level of differentiation would still be higher at non-neutral than neutral loci due to selection. Part of the figure is based on Fig. 1 in Nielsen et al. (2009b) spawning grounds simultaneously. In this case, the allele frequencies of neutral as well as non-neutral loci would be expected to differ between NA and NC. Differentiation would be a result of events during the historical period of isolation, presumably in allopatry. The allelic distribution at non-neutral loci could differ from that at neutral loci even under this scenario, and the overall extent of differentiation between NA and NC would depend on effective population sizes and the historical interplay of genetic drift, founder effects, and selection for either of the 2 units. Genetic drift will affect populations with a small effective population size $\left(N_{\mathrm{e}}\right)$. We are not aware of estimates of $N_{\mathrm{e}}$ in NA or $\mathrm{NC}$, and, arguably, current estimates would tell us little about $N_{\mathrm{e}}$ during periods of potential historical allopatric isolation. The North Atlantic has repeatedly been covered with ice during the Quaternary period, the last glacial maximum being $21 \mathrm{kyr}$ ago (Svendsen et al. 2004), and the sea level has been suggested to vary by up to $120-135 \mathrm{~m}$ in the past (Mitrovica 2003). In accordance with the historical isolation hypothesis genetic drift and founder effects are likely to have affected boreal populations under such dynamic conditions. However, it is also argued that large cod populations might have been connected in the recent past and that the weak genetic differentiation found (at neutral loci) is due to a rapid expansion of the population after the last glacial maximum (Pogson et al. 1995, Hardie et al. 2006, Pampoulie et al. 2008). Pogson et al. (1995) argued that gene flow is actually low enough to allow differentiation due to drift, but too little time has passed to detect this, especially in cod populations from adjacent regions. A similar conclusion was drawn from mtDNA studies in cod (Smith et al. 1989, Árnason et al. 1992). It remains unclear to what extent these arguments apply to NA and NC, although the historical isolation hypothesis has received some support (e.g. Møller 1968, 1969). 


\section{PAPER SELECTION}

The present paper reviews studies which compare empirical data from both Gadus morhua cod in the Barents Sea and cod along the coast and in the fjords of Norway. Papers about closely related topics like potential population subdivision within either NA or NC (e.g. Jørstad \& Nævdal 1989, Salvanes et al. 2004, Otterå et al. 2006) are excluded, as are studies of differences between other groups of cod throughout its range of distribution. Besides being newer and updated, this review differs from 2 previous reviews (Borisov et al. 1999, Imsland \& Jonsdottir 2003) by focusing on differences between NA and NC only, being more comprehensive, e.g. including behavioural and life-history characteristics, including papers using microsatellites and SNPs, and by not arguing in support of any one particular view.

\section{DO NA AND NC DIFFER IN CHARACTERISTICS OR MARKERS?}

Details from 54 peer-reviewed papers published from 1933 to 2009, comparing characteristics or genetic markers of Gadus morhua (NA and NC), are listed in Table 1. Thirty-eight $(70 \%)$ of the papers claim to demonstrate a significant difference in at least one of the characters or markers examined. Twelve (22\%) papers come to the opposite conclusion, whereas no obvious conclusion is drawn in 4 (7\%) papers.

Forty-one $(76 \%)$ of the papers are field studies, including at least 1 sample of NC from North Norway in addition to an NA sample, and $2(4 \%)$ are review papers. The remaining 11 (20\%) papers are experimental. Of the 11 experimental studies, 4 include cod originating from North Norway (defined as north of $65^{\circ} 00^{\prime} \mathrm{N}$ ); the remaining studies compare NA with coastal cod from southern parts of Norway (Fig. 1). Of the 11 experimental studies, 9 were carried out south of $61^{\circ} 00^{\prime} \mathrm{N}$ (Sognefjord) (Table 1, Fig. 1), which is far south of the areas of the current distribution of NA.

\section{POTENTIAL LIMITATIONS IN METHODS TO DISTINGUISH BETWEEN COD POPULATIONS}

Examples of papers suggesting limitations in the methods used to distinguish between groups of cod Gadus morhua are presented in Table 2, although a full literature review of this topic is outside the scope of the present paper.

There seems to be no disagreement that growth, sexual maturation, vertebra count and perhaps shape and growth of otoliths are severely influenced by environ- mental factors (Table 2). Concerning otoliths, the 3 experimental papers comparing NA and NC have studied 0-group or younger specimens. No study has examined the relative importance of genes and environments in the formation of the internal morphological features (shape of the innermost growth rings) used to categorize adult NA and NC (Otterlei et al. 2002, Stransky et al. 2008, Wennevik et al. 2008). This is a remarkable omission since internal otolith morphology is used to separate the NA and NC both for management purposes, e.g. by the International Council for the Exploration of the Sea (ICES), and for scientific studies as stated by Berg et al. (2005) and Stransky et al. (2008).

Several authors suggest that frequencies of $H b I$ alleles and Pan I alleles (nuclear DNA) are subject to environmental influences as well (Table 2), although the details of the dynamics of Pan I polymorphisms in cod populations remain unclear as pointed out by Karlsson \& Mork (2003) and Pogson \& Fevolden (2003).

Each of the allozymes LDH-3 and PGI-1 are claimed in 2 papers to be subject to environmental influence, whereas no such effects were found in another paper (Table 2). The microsatellites Gmo34, Gmo37 and Gmo132 are claimed to be non-neutral as well (Table 2), and Gmo34 seems to display linkage disequilibrium with Pan I (Westgaard \& Fevolden 2007). Although a few allozymes and microsatellites are subject to environmental forces, several others (not reported here) are presumably neutral. Strikingly, the 2 non-neutral allozymes (LDH-3 and PGI-1) and 2 of the 3 non-neutral microsatellites (Gmo34, and Gmo132) are also the only allozymes (Table 1, present study) and microsatellites (Westgaard \& Fevolden 2007 ) reported to differ significantly in frequencies and are therefore able to discriminate NA and NC.

The cytochrome $b$ part of the mtDNA in cod (Table 2) has passed neutrality tests, and the influence of the environment is concluded in 2 papers to be either absent or weak (Table 2). The consensus in the molecular literature is that mtDNA is a neutral marker (e.g. Marshall et al. 2009, but see Bazin et al. 2006). On the other hand, non-recombining genomes like mtDNA are to be considered a single locus, whereas studying potential differentiation at several loci is considered a more robust way of examining population structure.

What is left after removing field studies which use non-neutral characteristics and genetic markers, and have categorized specimens according to otoliths?

After removing studies applying non-neutral characteristics and markers, as well as studies which categorize specimens from otolith form (based on the arguments above), we are left with a total of 17 studies (shown in italics in Table 1). Seven studies present data supporting difference between NA and NC, 7 suggest 


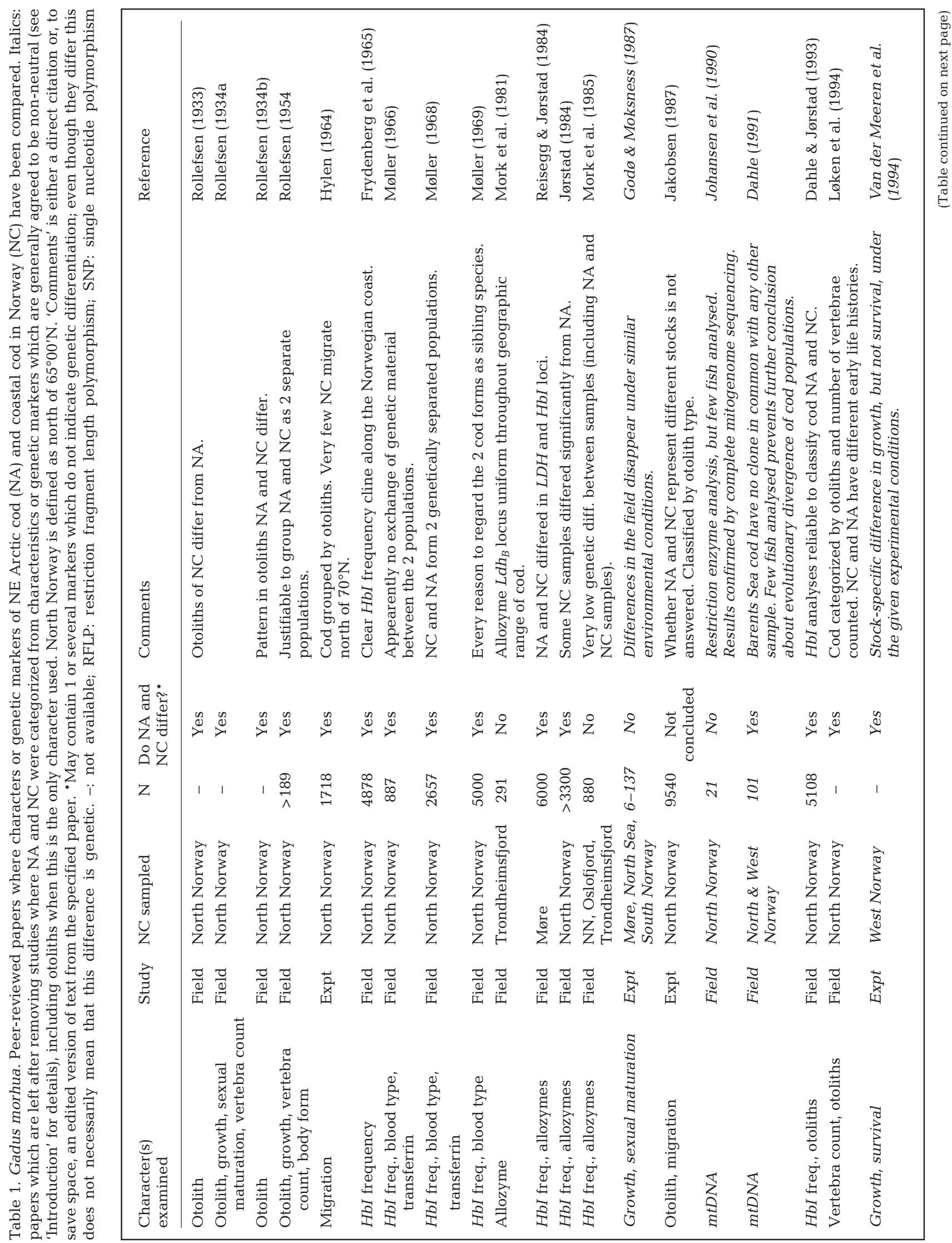




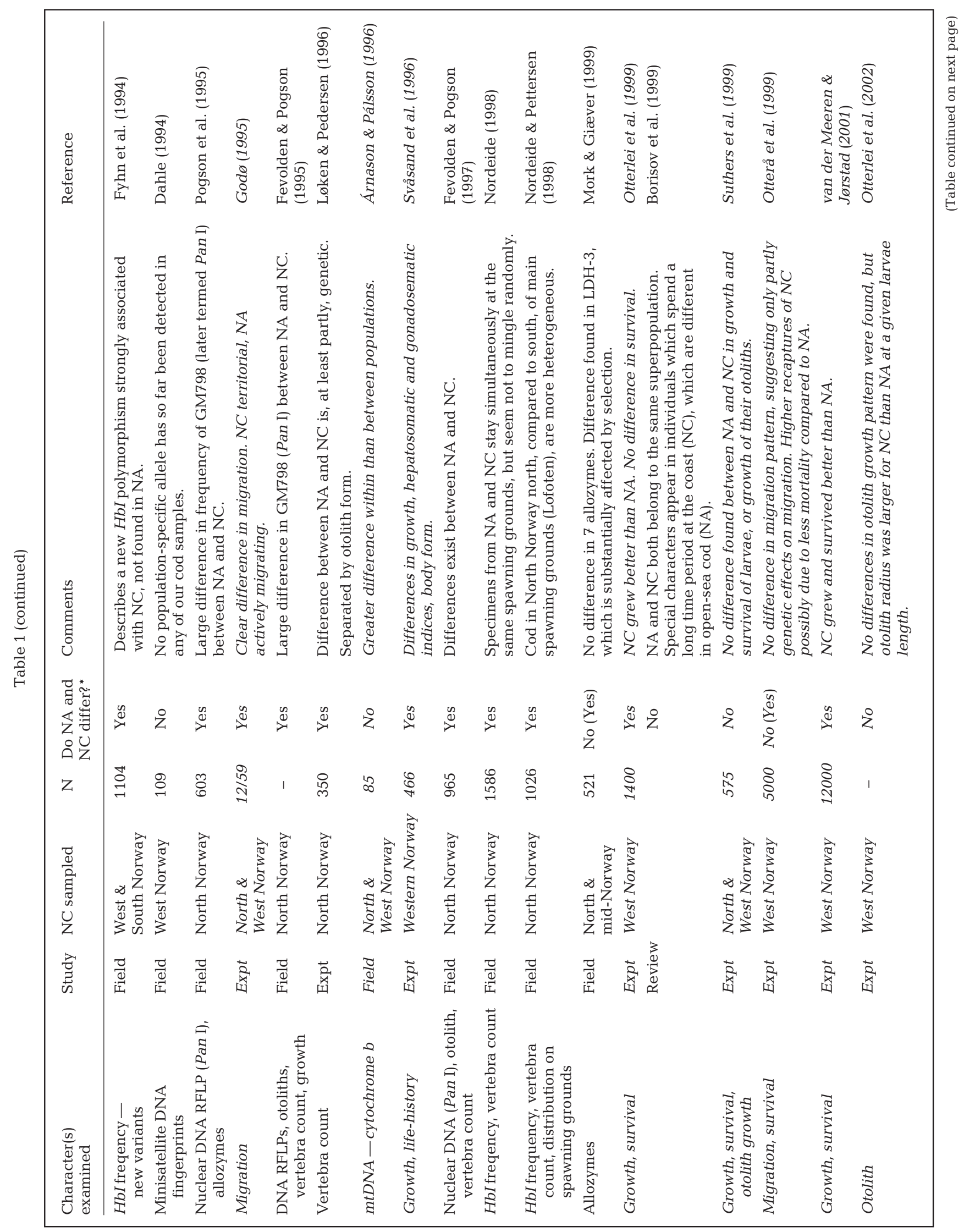




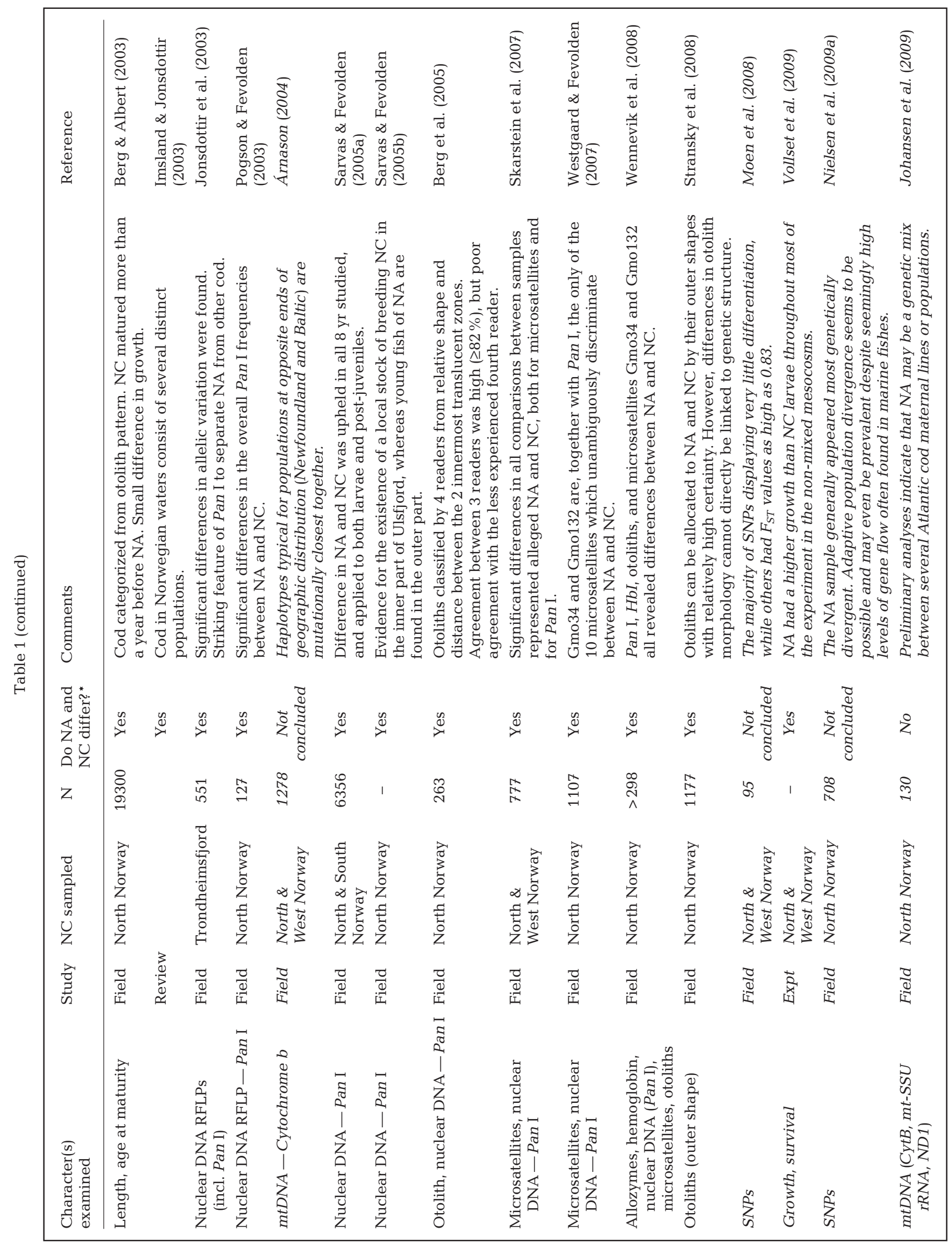


Table 2. Examples of peer-reviewed papers where authors make claims about whether or not the characters or genetic markers, used to distinguish between North-East Arctic cod (NA) Gadus morhua and coastal cod (NC) in the North Atlantic, are subject to natural selection. This table gives examples and is not meant to show a complete review of every paper commenting on the subject. 'Comments' is either a direct citation or, to save space, an edited version of text from the paper

\begin{tabular}{|c|c|c|c|c|}
\hline $\begin{array}{l}\text { Character/ } \\
\text { genetic } \\
\text { marker }\end{array}$ & $\begin{array}{l}\text { Field/ } \\
\text { experi- } \\
\text { ment }\end{array}$ & $\begin{array}{l}\text { Influenced } \\
\text { by environ- } \\
\text { ments? }\end{array}$ & Comments & Reference \\
\hline \multicolumn{5}{|l|}{ Otolith } \\
\hline & Expt & Yes & $\begin{array}{l}\text { The experiments indicate that the formation of zones in otoliths } \\
\text { of the cod is influenced by temperature directly or indirectly. }\end{array}$ & Dannevig (1956) \\
\hline & Expt & Yes & $\begin{array}{l}\text { The increment width series of the lapillus - otolith growth } \\
\text { history - and the relative daily growth rate were not } \\
\text { significantly different among NA and NC. }\end{array}$ & Suthers et al. (1999) \\
\hline & Expt & Yes & $\begin{array}{l}\text { No significant differences in otolith growth pattern were } \\
\text { found among co-reared cod larvae from NA and NC. Little } \\
\text { information exist concerning the relative importance of } \\
\text { environmental and genetic factors affecting otolith growth. }\end{array}$ & $\begin{array}{l}\text { Otterlei et } \\
\text { al. (2002) }\end{array}$ \\
\hline & Field & ? & $\begin{array}{l}\text { Relative effects of environment and genetic background on } \\
\text { otolith shape and structure is not clear. No published studies } \\
\text { on this topic. }\end{array}$ & $\begin{array}{l}\text { Wennevik et al. } \\
(2008)\end{array}$ \\
\hline & Field & Yes & $\begin{array}{l}\text { Differences in otolith morphology cannot directly be linked } \\
\text { to genetic structure. Differences in environmental conditions } \\
\text { seem to have a considerable influence on how otolith growth } \\
\text { increments and consequently otolith outer shapes are formed. } \\
\text { There is a genetic component of otolith growth, but for NA } \\
\text { and NC, there is likely to be a an environmental and physiolo- } \\
\text { gical basis for the differences in otolith morphology. }\end{array}$ & $\begin{array}{l}\text { Stransky et al. } \\
(2008)\end{array}$ \\
\hline \multicolumn{5}{|c|}{ Vertebra count } \\
\hline & Field & Yes & $\begin{array}{l}\text { Fisheries biologists agree that external factors, like tempera- } \\
\text { ture, are able to change the mean value of the characters (like } \\
\text { vertebra count) by which races are defined. However, differen- } \\
\text { ces in such characters might have a genetic component as well. }\end{array}$ & Schmidt (1930) \\
\hline & Expt & Yes & $\begin{array}{l}\text { The number of vertebrae in teleosts is thus far more plastic } \\
\text { than has been assumed hitherto. }\end{array}$ & Tåning (1952) \\
\hline & Expt & Yes & $\begin{array}{l}\text { Vertebrae number in fish is fixed during the early part of the } \\
\text { embryonic period. }\end{array}$ & Fahy (1976 \\
\hline & Field & Yes & $\begin{array}{l}\text { Inverse relationship between temperature during early } \\
\text { development and mean vertebral number is established for } \\
\text { cod populations throughout the North Atlantic. To what extent } \\
\text { the differences is inherited is unknown. }\end{array}$ & Brander (1979) \\
\hline & Field & Yes & $\begin{array}{l}\text { Meristic differences have usually been related to temperature, } \\
\text { with the additional possibility of genetic effects. }\end{array}$ & Templeman (1981) \\
\hline & Review & Yes & $\begin{array}{l}\text { Meristic differences may be present and useful (to separate } \\
\text { stocks) when spawning times and temperatures differ suffi- } \\
\text { ciently to produce them. Genetic factors may also influence } \\
\text { the production of meristic characters. }\end{array}$ & Templeman (1983) \\
\hline & Expt & $\begin{array}{l}\text { Not } \\
\text { concluded }\end{array}$ & $\begin{array}{l}\text { There was an inverse relationship between temperature and } \\
\text { vertebrae count in the broodstock group. The differences in } \\
\text { vertebrae number between NC and NA cod are, at least in } \\
\text { part, genetically determined. }\end{array}$ & $\begin{array}{l}\text { Løken \& Pedersen } \\
(1996)\end{array}$ \\
\hline Growth & Field & Yes & $\begin{array}{l}\text { A simple model in which catch weight-at-age is a function of } \\
\text { the product of age x temperature accounts for } 92 \% \text { of the } \\
\text { variance for } 2-4 \text { year old cod from } 17 \text { stocks throughout the } \\
\text { North Atlantic. }\end{array}$ & Brander (1995) \\
\hline & Expt & Yes & $\begin{array}{l}\text { Larval and juvenile growth was temperature and } \\
\text { size dependent. }\end{array}$ & $\begin{array}{l}\text { Otterlei et al. } \\
(2002)\end{array}$ \\
\hline \multicolumn{5}{|c|}{$\mathrm{HbI}$ frequency } \\
\hline & Expt & Yes & $\begin{array}{l}H b I-2 \text { hemoglobin combines oxygen better at low temperatures, } \\
\text { and } H b I-1 \text { at high temperatures. Haemoglobin polymorphism } \\
\text { of the cod is undoubtly maintained by selective mechanisms. }\end{array}$ & $\begin{array}{l}\text { Karpov \& Novikov } \\
(1980)\end{array}$ \\
\hline
\end{tabular}


Table 2 (continued)

\begin{tabular}{|c|c|c|c|c|}
\hline $\begin{array}{l}\text { Character/ } \\
\text { genetic } \\
\text { marker }\end{array}$ & $\begin{array}{l}\text { Field/ } \\
\text { experi- } \\
\text { ment }\end{array}$ & $\begin{array}{l}\text { Influenced } \\
\text { by environ- } \\
\text { ments? }\end{array}$ & Comments & Reference \\
\hline & Field & Yes & $\begin{array}{l}\text { The apparent existence of considerable natural and artificial } \\
\text { selection forces acting upon cod haemoglobin genotypes } \\
\text { makes } H b I \text { allele frequencies unreliable for use in } \\
\text { population structure analyses. }\end{array}$ & Mork et al. (1983) \\
\hline & Field & Yes & $\begin{array}{l}\text { Significant differences in mean length between the } 3 \text { common } \\
H b I \text { genotypes. There is reason to doubt the reliability of } H b I \\
\text { characteristics when used in cod population structure analyses. }\end{array}$ & Mork et al. (1984) \\
\hline & Field & Yes & $\begin{array}{l}\text { The results appear to support recent reports on considerable } \\
\text { selection effects at } H b I \text {, and stress the unreliability of allele } \\
\text { frequencies at this locus for use in studies of the genetic } \\
\text { population structure of cod. }\end{array}$ & $\begin{array}{l}\text { Mork \& Sundnes } \\
(1985 b)\end{array}$ \\
\hline & Expt & No & $H b I(2-2)$ growth faster in all 3 experimental temperatures. & Nævdal et al. (1992) \\
\hline & Expt & Yes & $\begin{array}{l}\mathrm{HbI}(2-2) \text { is most efficient } \mathrm{O}_{2} \text { carrier at low temperatures. } \\
\text { Haemoglobin polymorphism in cod seems to be correlated } \\
\text { with physiological performance. }\end{array}$ & Brix et al. (1998) \\
\hline & Expt & Yes & $\begin{array}{l}H b I-2 \text { cod preferred a temperature of } 8^{\circ} \mathrm{C} \text { while } H b I-1 \text { cod } \\
\text { preferred } 15^{\circ} \mathrm{C} \text {. The results indicate that environmental } \\
\text { temperature changes will lead to a distributional change in } \\
\text { the different haemoglobin types of Atlantic cod. }\end{array}$ & $\begin{array}{l}\text { Petersen \& } \\
\text { Steffensen (2003) }\end{array}$ \\
\hline & Expt & Yes & $\begin{array}{l}H b I(2-2) \text { is better fitted to cold temperatures than } H b I(1-1) \\
\text { in being able to transport more } \mathrm{O}_{2} \text { from the environment } \\
\text { to the tissue. }\end{array}$ & Brix et al. (2004) \\
\hline & Expt & Yes & $\begin{array}{l}\text { The genotype } H b \text {-I }(2 / 2) \text { displayed the overall highest growth } \\
\text { rate in the temperature range } 13-16^{\circ} \mathrm{C} \text {, whereas the } H b-\mathrm{I}(1 / 1) \\
\text { genotype showed the highest overall growth at the lowest } \\
\text { temperature }\left(7^{\circ} \mathrm{C}\right) \text {. }\end{array}$ & $\begin{array}{l}\text { Imsland et al. } \\
(2004)\end{array}$ \\
\hline & Expt & No & $\begin{array}{l}\text { In juvenile cod, there is no selective advantage to having } \\
\text { a particular } H b \text { genotype with regards to the capacity to } \\
\text { withstand ecologically relevant environmental challenges. }\end{array}$ & $\begin{array}{l}\text { Gamperl et al. } \\
(2009)\end{array}$ \\
\hline \multicolumn{5}{|l|}{ Allozymes } \\
\hline LDH-3 & Expt & Yes & $\begin{array}{l}\text { Apparently, } L D H-3 \text { is not selectively neutral, and allele } \\
\text { frequency differences at this loci should not be interpreted as } \\
\text { markers of reproductive isolation. }\end{array}$ & $\begin{array}{l}\text { Mork \& Sundnes } \\
\text { (1985a) }\end{array}$ \\
\hline LDH-3 & Expt & No & $\begin{array}{l}\text { No clear associations between growth rate and genotypes of } \\
\text { LDH were found at any temperature. }\end{array}$ & $\begin{array}{l}\text { Nævdal et al. } \\
(1992)\end{array}$ \\
\hline LDH-3 & Field & Yes & $\begin{array}{l}\text { The Hardy-Weinberg anomalities at } L D H-3^{*} \text { documented in } \\
\text { this and previous studies suggest that this locus is substantially } \\
\text { affected by environmental selection and that the allele } \\
\text { frequencies is not stable enough to be used as population } \\
\text { characteristics in cod. }\end{array}$ & $\begin{array}{l}\text { Mork \& Giæver } \\
\text { (1999) }\end{array}$ \\
\hline PGI-1 & Expt & Yes & $\begin{array}{l}\text { Apparently, PGI-1 is not selectively neutral, and allele } \\
\text { frequency differences at this loci should not be interpreted } \\
\text { as markers of reproductive isolation. }\end{array}$ & $\begin{array}{l}\text { Mork \& Sundnes } \\
\text { (1985a) }\end{array}$ \\
\hline PGI-1 & Expt & No & $\begin{array}{l}\text { No clear associations between growth rate and genotypes of } \\
P G I-1 \text { were found at any of the temperatures } 6,10 \text { and } 14^{\circ} \mathrm{C} \text {. }\end{array}$ & $\begin{array}{l}\text { Nævdal et al. } \\
(1992)\end{array}$ \\
\hline \multicolumn{5}{|c|}{ Microsatellites } \\
\hline Gmo34 & Field & Yes & Two different models proved Gmo34 to be non-neutral. & $\begin{array}{l}\text { Westgaard \& } \\
\text { Fevolden (2007) }\end{array}$ \\
\hline Gmo37 & Field & Yes & $\begin{array}{l}\text { Simulation tests indicated that variation at Gmo37 deviates } \\
\text { significantly from neutral expectations. }\end{array}$ & $\begin{array}{l}\text { Skarstein et al. } \\
(2007)\end{array}$ \\
\hline Gmo132 & Field & Likely & $\begin{array}{l}\text { Observed deficit of heterozygotes of Gmo132 believed to be } \\
\text { due to natural selection, Wahlund effects and/or null alleles. }\end{array}$ & $\begin{array}{l}\text { Karlsson \& Mork } \\
(2005)\end{array}$ \\
\hline Gmo132 & Field & Yes & $\begin{array}{l}\text { Our analysis revealed a highly divergent pattern of genetic } \\
\text { differentiation and large differences in levels of variability at } \\
\text { Gmo132 among populations, which was inconsistent with } \\
\text { neutral expectations. }\end{array}$ & $\begin{array}{l}\text { Nielsen et al. } \\
(2006)\end{array}$ \\
\hline
\end{tabular}


Table 2 (continued)

\begin{tabular}{|c|c|c|c|c|}
\hline $\begin{array}{l}\text { Character/ } \\
\text { genetic } \\
\text { marker }\end{array}$ & $\begin{array}{l}\text { Field/ } \\
\text { experi- } \\
\text { ment }\end{array}$ & $\begin{array}{l}\text { Influenced } \\
\text { by environ- } \\
\text { ments? }\end{array}$ & Comments & Reference \\
\hline Gmo132 & Field & Yes & Two different models proved Gmo132 to be non-neutral. & $\begin{array}{l}\text { Westgaard \& } \\
\text { Fevolden }(2007)\end{array}$ \\
\hline Gmo132 & Field & Yes & $\begin{array}{l}\text { Simulation tests indicated that variation at Gmo132 deviates } \\
\text { significantly from neutral expectations. }\end{array}$ & $\begin{array}{l}\text { Skarstein et al. } \\
(2007)\end{array}$ \\
\hline \multicolumn{5}{|c|}{ Nuclear DNA RFLP (Pan I) } \\
\hline & Field & Yes & Significant differences in growth rates among $\operatorname{Pan}$ I genotypes. & $\begin{array}{l}\text { Fevolden \& } \\
\text { Pogson (1995) }\end{array}$ \\
\hline & Field & Yes & $\begin{array}{l}\text { This suggests the possibility that the } 3 \text { polymorphisms scored } \\
\text { by this cDNA clone (including Pan I) may be tightly linked to } \\
\text { a site undergoing selection. }\end{array}$ & $\begin{array}{l}\text { Pogson et al. } \\
\text { (1995) }\end{array}$ \\
\hline & Field & Yes & $\begin{array}{l}\text { Strong linkage disequilibrium at the Pan I gene region, which } \\
\text { opens the possibility that selection at a linked locus may be } \\
\text { responsible for the large differences among NA and NC. }\end{array}$ & $\begin{array}{l}\text { Fevolden \& } \\
\text { Pogson (1997) }\end{array}$ \\
\hline & Field & Yes & $\begin{array}{l}\text { Nucleotide sequence of } 24 \text { Pan I alleles showed strong evidence } \\
\text { for an unusual mix of balancing and directional selection } \\
\text { but no evidence of stable geographically varying selection. }\end{array}$ & Pogson (2001) \\
\hline & Field & Yes & $\begin{array}{l}\text { Postsettlement selection acting on cohorts cannot be responsible } \\
\text { for the genetic differences between NC and NA. Our results are } \\
\text { consistent with a recent separation of NC and NA rendered more } \\
\text { visible by the action of diversifying selection in the } 2 \text { environments. }\end{array}$ & $\begin{array}{l}\text { Pogson \& } \\
\text { Fevolden (2003) }\end{array}$ \\
\hline & Field & Yes & $\begin{array}{l}\text { A point estimate of Pan I allele frequencies from a single sample } \\
\text { is an unreliable characteristics of the cod population in Trond- } \\
\text { heimsfjorden because observed allele frequencies depend } \\
\text { heavily on sampling year, age composition, microlocality } \\
\text { and sex ratio of the sample. }\end{array}$ & $\begin{array}{l}\text { Karlsson \& Mork } \\
(2003)\end{array}$ \\
\hline & Field & Yes & $\begin{array}{l}\text { Positive selection was observed in the IV1 domain in both } \\
\text { G. morhua allelic lines. }\end{array}$ & $\begin{array}{l}\text { Pogson \& Mesa } \\
(2004)\end{array}$ \\
\hline & Field & Yes & $\begin{array}{l}\text { Strong correlations between Pan I allele frequencies and key } \\
\text { environmental variables suggest that environmental conditions } \\
\text { play an important role in determining the distribution of } \\
\text { different Pan I genotypes. }\end{array}$ & $\begin{array}{l}\text { Case et al. } \\
(2005)\end{array}$ \\
\hline & Expt & Yes & $\begin{array}{l}\text { Larvae carrying the } \operatorname{Pan} \mathrm{I}^{*} \text { ab genotype exhibited significantly } \\
\text { higher standard length, dry weight, and RNA: DNA ratio } \\
\text { (condition factor) than did larvae that carried the Pan } \mathrm{I}^{*} \text { bb } \\
\text { genotype, potentially indicating selection. }\end{array}$ & $\begin{array}{l}\text { Case et al. } \\
(2006)\end{array}$ \\
\hline & Field & Yes & Pan I locus is acknowledged to be non-neutral. & $\begin{array}{l}\text { Westgaard \& } \\
\text { Fevolden }(2007)\end{array}$ \\
\hline & Field & $\begin{array}{l}\text { To a limited } \\
\text { degree }\end{array}$ & $\begin{array}{l}\text { The large difference observed at the Pan I locus, where NC } \\
\text { and NA are almost fixed for different alleles, cannot result } \\
\text { from selection alone. }\end{array}$ & $\begin{array}{l}\text { Wennevik et al. } \\
(2008)\end{array}$ \\
\hline \multicolumn{5}{|l|}{ mtDNA } \\
\hline $\begin{array}{l}\text { Cytochrome } \\
b\end{array}$ & Field & No & $\begin{array}{l}\text { The variation passes several neutral-theory tests and is thus } \\
\text { suitable as markers for studying population differentiation. }\end{array}$ & $\begin{array}{l}\text { Árnason \& } \\
\text { Pálsson (1996) }\end{array}$ \\
\hline $\begin{array}{l}\text { Cytochrome } \\
b\end{array}$ & Field & No & $\begin{array}{l}\text { Natural selection acting directly on these mtDNA haplotypes is } \\
\text { either absent or weak. }\end{array}$ & Árnason (2004) \\
\hline
\end{tabular}

the opposite, whereas 3 do not provide a conclusion (Table 1). Thus, this filtering of papers does not bring us any closer to an agreement concerning the cod population structure in the NE Atlantic.

Of the 14 papers offering conclusions, none are experimental studies which simultaneously satisfy the criteria of both being carried out within their natural environments in North Norway and including NC from North Norway (north of $65^{\circ} 00^{\prime} \mathrm{N}$ ). Of the field studies (of the concluding 14), only mtDNA studies were left (Johansen et al. 1990, 2009, Dahle 1991, Árnason \& Pálsson 1996). 


\section{CONCLUSIONS AND PERSPECTIVES}

Of the 54 papers published on the topic (Table 1), $70 \%$ conclude positively concerning genetic differences between the NA (migratory) and NC (stationary) cod Gadus morhua in the NE Atlantic Ocean. Population genetic differentiation has been identified at several loci, such as the pantophysin and hemoglobin genes, that are apparently subject to strong positive selection. However, after disregarding papers that are based on non-neutral loci, and are therefore less suited to discerning population subdivisions, we are still far from a proper understanding of the population genetic structure of Atlantic cod in these waters.

After $80 \mathrm{yr}$ of studies, it is reasonable to ask why no agreement has been reached concerning population structure of NA and NC. Methodological limitations are crucial, in particular the inability to analyse more than a few characteristics and loci. Another reason is too much attention to 'informative' characters or genetic markers that show differences, which later turn out not to live up to the initial expectations. Such exaggerated attention to a few markers might occur at the expense of neutral ones. This again emphasises the importance of testing new markers against neutrality expectations.

Despite mounting empirical evidence from a number of species, the extent of genetic differentiation among natural populations is still difficult to predict. We suggest 3 different approaches in future studies to reveal whether NA and NC are 2 genetically different noninterbreeding populations. Firstly and foremost, the genomic variation of NA and NC should be compared using next-generation sequencing techniques. The most obvious contribution of the population genomics approach will be the vast increase in precision of the estimation of population parameters that require neutral loci. There is also the exciting prospect of being able to identify the distribution of loci affecting fitness across the genome and the genetic basis of local adaptation (Allendorf et al. 2010). The basis for cod population genomics is being provided by the Centre for Integrative Genetics (www.cigene.no) and by the ongoing Cod Genome Project (http://codgenome.no/), which aims to provide a high-quality, whole-genome sequence of the cod. Our research group currently uses SOLiD ligation sequencing of pooled DNA samples to produce genome-wide comparisons of the NA and NC at the population scale. Secondly, large-scale controlled experiments should compare fitness components like fertilization success, survival, mass and growth of the $F_{1}$ - and $F_{2}$-hybrids to pure lines of NA and NC, and care must be taken to catch the NA parents (P-generation) in the Barents Sea and the NC parents where they are traditionally known to be the only spawners. Thirdly, controlled experiments should examine to which degree the innermost annual growth zone of otoliths are influenced by genes and environments. These experiments should be carried out with NC from North Norway (or NW Russia) and within the geographical range of both cod groups, and as close as possible to the environmental conditions normally met by both NA and NC.

Acknowledgements. We thank 2 anonymous reviewers for critical comments and constructive suggestions which improved the quality of this paper.

\section{LITERATURE CITED}

Aglen A (2010) Kan kysttorsk og skrei forvaltes hver for seg? In: Havforskningsrapporten 2010-Kyst og havbruk. Available at: www.imr.no/filarkiv/kyst_og_havbruk_2009/ 1.8_Kan_kysttorsk_og_skrei_forvaltes_hver_for_seg.pdf

Allendorf FW, Hohenlohe PA, Luikart G (2010) Genomics and the future of conservation genetics. Nat Rev Genet 11: $697-709$

Árnason E (2004) Mitochondrial cytochrome $b$ DNA variation in the high-fecundity Atlantic cod: trans-Atlantic clines and shallow gene genealogy. Genetics 166:1871-1885

Árnason E, Pálsson S (1996) Mitochondrial cytochrome $b$ DNA sequence variation of Atlantic cod, Gadus morhua, from Norway. Mol Ecol 5:715-724

Árnason E, Pálsson S, Arason A (1992) Gene flow and lack of population differentiation in Atlantic cod, Gadus morhua L., from Iceland, and a comparison of cod from Norway and Newfoundland. J Fish Biol 40:751-770

Bazin E, Glémin S, Galtier N (2006) Population size does not influence mitochondrial diversity in animals. Science 312: 570-572

Beebee T, Rowe G (2008) An introduction to molecular ecology. Oxford University Press, Oxford

$>$ Berg E, Albert OT (2003) Cod in fjords and coastal waters of North Norway: distribution and variation in length and maturity at age. ICES J Mar Sci 60:787-797

Berg E, Sarvas TH, Fevolden SE, Salberg AB (2005) Accuracy and precision in stock separation of north-east Arctic and Norwegian coastal cod by otoliths - comparing readings, image analyses and a genetic method. Mar Freshw Res 56: $753-762$

Bergstad OA, Jørgensen T, Dragesund O (1987) Life history and ecology of the gadoid resources of the Barents Sea. Fish Res 5:119-161

Borisov VM, Ponomarenko VP, Yaragina NA (1999) A critical review of the population status in coastal cod (Gadus morhua) from Barents Sea region of Norway. J Ichthyol 39: 18-28

Brander KM (1979) The relationship between vertebral number and water temperature in cod. J Cons Int Explor Mer 38:286-292

Brander K (1994) Spawning and life history information for North Atlantic cod stocks. In: Brander K (ed) ICES Cooperative Research Report No. 205. ICES, Copenhagen

Brander KM (1995) The effect of temperature on growth of Atlantic cod (Gadus morhua L.). ICES J Mar Sci 52:1-10

> Brawn VM (1961a) Aggressive behaviour in the cod (Gadus callarias L.). Behaviour 18:107-147

- Brawn VM (1961b) Reproductive behaviour of the cod (Gadus callarias L.). Behaviour 18:177-198 
Brawn VM (1961c) Sound production by the cod (Gadus callarias L.). Behaviour 18:239-255

Brix O, Forås E, Strand I (1998) Genetic variation and functional properties of Atlantic cod hemoglobins: introducing a modified tonometric method for studying fragile hemoglobins. Comp Biochem Physiol A 119A:575-583

> Brix O, Thorkildsen S, Colosimo A (2004) Temperature acclimation modulates the oxygen binding properties of the Atlantic cod (Gadus morhua L.) genotypes HbI*1/1, $H b I^{*} 1 / 2$, and $H b I^{*} 2 / 2$ by changing the concentrations of their major hemoglobin components (results from growth studies at different temperatures). Comp Biochem Physiol A 138:241-251

> Case RAJ, Hutchinson WF, Hauser L, Van Oosterhout C, Carvalho GR (2005) Macro- and micro-geographic variation in pantophysin (Pan I) allele frequencies in NE Atlantic cod Gadus morhua. Mar Ecol Prog Ser 301:267-278

Case RAJ, Hutchinson WF, Hauser L, Buehler V and others (2006) Association between growth and Pan $I^{*}$ genotype within Atlantic cod full-sibling families. Trans Am Fish Soc 135:241-250

Dahle G (1991) Cod, Gadus morhua L., populations identified by mitochondrial DNA. J Fish Biol 38:295-303

Dahle G (1994) Genetic studies of families of Arcto-Norwegian and Norwegian coastal cod: preliminary random amplified polymorphic deoxyribonucleic acid studies. ICES Mar Sci Symp 198:684-687

Dahle G, Jørstad KE (1993) Haemoglobin variation in cod-a reliable marker for Arctic cod (Gadus morhua L.). Fish Res 16:301-311

Dannevig A (1956) The influence of temperature on the formation of zones in scales and otoliths of young cod. Fiskeridir Skr Ser Havunders 11:3-16

Engen F, Folstad I (1999) Cod courtship song: A song at the expense of dance? Can J Zool 77:542-550

Fahy WE (1976) The morphological time of fixation of the total number of vertebrae in Fundulus majalis (Walbaum). J Cons Int Explor Mer 36:243-250

> Ferguson A (1994) Molecular genetics in fisheries: current and future perspectives. Rev Fish Biol Fish 4:379-383

Fevolden SE, Pogson GH (1995) Differences in nuclear DNA RFLPs between the Norwegian coastal and the Northeast Arctic population of Atlantic cod. In: Skjoldal HR, Hopkins C, Erikstad KE, Leinaas HP (eds) Ecology of fjords and coastal waters. Elsevier Science B.V., Amsterdam

Fevolden SE, Pogson GH (1997) Genetic divergence at the synaptophysin (Syp I) locus among Norwegian coastal and north-east Arctic populations of Atlantic cod. J Fish Biol 51:895-908

Frydenberg O, Møller D, Næevdal G, Sick K (1965) Haemoglobin polymorphism in Norwegian cod populations. Hereditas 53:257-271

Fyhn U, Brix O, Nævdal G, Johansen T (1994) New variants of the hemoglobins of Atlantic cod: a tool to discriminate between coastal and arctic cod populations. ICES Mar Sci Symp 198:666-670

Gamperl AK, Busby CD, Hori TSF, Afonso LOB, Hall JR (2009) Hemoglobin genotype has minimal influence on the physiological response of juvenile Atlantic cod (Gadus morhua) to environmental challenges. Physiol Biochem Zool 82:483-494

Godø OR (1995) Transplantation-tagging-experiments in preliminary studies of migration of cod off Norway. ICES J Mar Sci 52:955-962

Godø OR, Moksness E (1987) Growth and maturation of Norwegian coastal cod and northeast Arctic cod under different conditions. Fish Res 5:235-242
Hardie DC, Gillett RM, Hutchings JA (2006) The effects of isolation and colonization history on the genetic structure of marine-relict populations of Atlantic cod (Gadus morhua) in the Canadian Arctic. Can J Fish Res Aquat Sci 63: 1830-1839

> Hohenlohe PA, Bassham S, Etter PD, Stiffler N, Johnson EA, Cresko WA (2010) Population genomics of parallel adaptation in threespine stickleback using sequenced RAD tags. PLoS Genet 6:e1000862

Hutchings JA, Bishop TD, McGregor-Shaw CR (1999) Spawning behaviour of Atlantic cod, Gadus morhua: evidence of mate competition and mate choice in a broadcast spawner. Can J Fish Aquat Sci 56:97-107

Hylen A (1964) Coastal cod and skrei in the Lofoten area. Fiskeridir Skr Ser Havunders 13:27-42

Imsland AK, Jonsdottir ODB (2003) Linking population genetics and growth properties of Atlantic cod. Rev Fish Biol Fish 13:1-26

Imsland AK, Foss A, Naevdal G, Johansen T, Folkvord A, Stefansson SO, Jonassen TM (2004) Variations in growth in haemoglobin genotypes of Atlantic cod. Fish Physiol Biochem 30:47-55

> Jakobsen T (1987) Coastal cod in northern Norway. Fish Res 5:223-234

> Johansen S, Guddal PH, Johansen T (1990) Organization of the mitochondrial genome of Atlantic cod Gadus morhua. Nucleic Acids Res 18:411-419

Johansen SD, Coucheron DH, Andreassen M, Karlsen BO and others (2009) Large-scale sequence analyses of Atlantic cod. New Biotechnol 25:263-271

Jonsdottir ODB, Imsland AK, Atladottir OY, Danielsdottir AK (2003) Nuclear DNA RFLP variation of Atlantic cod in the North Atlantic Ocean. Fish Res 63:429-436

Jørstad KE (ed) (1984) Genetic analyses of cod in northern Norway. In: Dahl E, Danielsen DS, Moksness E, Solemdal $\mathrm{P}$ (eds) The propagation of cod (Gadus morhua L). Oluf Rasmussen A/S, Skien, p 745-760

Jørstad KE, Nævdal G (1989) Genetic variation and population structure of cod, Gadus morhua L., in some fjords in northern Norway. J Fish Biol 35(Suppl):245-252

Karlsson S, Mork J (2003) Selection-induced variation at the pantophysin locus (Pan I) in a Norwegian fjord population of cod (Gadus morhua L.). Mol Ecol 12:3265-3274

Karlsson S, Mork J (2005) Deviation from Hardy-Weinberg equilibrium, and temporal instability in allele frequencies at microsatellite loci in a local population of Atlantic cod. ICES J Mar Sci 62:1588-1596

Karpov LK, Novikov GG (1980) The haemoglobin alloforms in cod, Gadus morhua (Gadiformes, Gadidae), their functional characteristics and occurrence in populations. J Ichthyol 20:45-49 (translated from Russian)

> Kjesbu OS (1989) The spawning activity of cod, Gadus morhua L. J Fish Biol 34:195-206

> Lewontin RC, Cockerham CC (1959) The goodness-of-fit for detecting natural selection in random mating populations. Evolution 13:561-564

Løken S, Pedersen T (1996) Effect of parent type and temperature on vertebrae number in juvenile cod, Gadus morhua (L.), in northern Norway. Sarsia 80:293-298

Løken S, Pedersen T, Berg E (1994) Vertebrae numbers as an indicator for the recruitment mechanism of coastal cod of northern Norway. ICES Mar Sci Symp 198:510-519

Lowe WH, Allendorf FW (2010) What can genetics tell us about population connectivity? Mol Ecol 19:3038-3051

Mardis ER (2008a) The impact of next-generation sequencing technology on genetics. Trends Genet 24:133-141

Mardis ER (2008b) Next-generation DNA sequencing meth- 
ods. Annu Rev Genomics Hum Genet 9:387-402

Marshall HD, Coulson MW, Carr SM (2009) Near neutrality, rate heterogeneity, and linkage govern mitochondrial genome evolution in Atlantic cod (Gadus morhua) and other gadine fish. Mol Biol Evol 26:576-589

Mitrovica JX (2003) Recent controversies in predicting postglacial sea-level change. Quat Sci Rev 22:127-133

Moen T, Hayes B, Nilsen F, Delghandi M and others (2008) Identification and characterisation of novel SNP markers in Atlantic cod: evidence for directional selection. BMC Genet 9:18

Møller D (1966) Genetic differences between cod groups in the Lofoten area. Nature 212:824-824

Møller D (1968) Genetic diversity in spawning cod along the Norwegian coast. Hereditas 60:1-32

Møller D (1969) The relationship between arctic and coastal cod in their immature stages illustrated by frequencies of genetic characters. Fiskeridir Skr Ser Havunders 15: 220-223

Mork J, Giæver M (1999) Genetic structure of cod along the coast of Norway: results from isozyme studies. Sarsia 84: $157-168$

- Mork J, Sundnes G (1985a) 0-group cod (Gadus morhua) in captivity: different survival of certain genotypes. Helgol Meeresunters 39:63-70

Mork J, Sundnes G (1985b) Haemoglobin polymorphism in Atlantic cod (Gadus morhua): allele frequency variation between yearclasses in a Norwegian fjord stock. Helgol Meeresunters 39:55-62

Mork J, Giskeødegård R, Sundnes G (1981) LDH gene frequencies in cod samples from two locations on the Norwegian coast. J Cons Int Explor Mer 39:110-113

Mork J, Giskeødegård R, Sundnes G (1983) Haemoglobin polymorphism in Gadus morhua: genotypic differences in maturing age and within-season gonad maturation. Helgol Meeresunters 36:313-322

Mork J, Giskeødegård R, Sundnes G (1984) Population genetic studies in cod (Gadus mohua L.) by means of the haemoglobin polymorphism; observations in a Norwegian coastal population. Fiskeridir Skr Ser Havunders 17: 449-471

Mork J, Ryman N, Ståhl G, Sundnes G (1985) Genetic variation in Atlantic cod (Gadus morhua) throughout its range. Can J Fish Aquat Sci 42:1580-1587

Nævdal G, Folkvord A, Otterlei E, Thorkildsen S (1992) Growth rate related to genotype of 0 -group cod at three environmental temperatures. Sarsia 77:71-73

> Nielsen R (2005) Molecular signatures of natural selection. Annu Rev Genet 39:197-218

> Nielsen EE, Hansen MM, Meldrup D (2006) Evidence of microsatellite hitch-hiking selection in Atlantic cod (Gadus morhua L.): implications for inferring population structure in nonmodel organisms. Mol Ecol 15:3219-3229

Nielsen EE, Hemmer-Hansen J, Poulsen N, Loeschcke V and others (2009a) Genomic signatures of local directional selection in a high gene flow marine organism; the Atlantic cod (Gadus morhua). BMC Evol Biol 9:276

Nielsen EE, Hemmer-Hansen J, Larsen PF, Bekkevold D (2009b) Population genomics of marine fishes: identifying adaptive variation in space and time. Mol Ecol 18: 3128-3150

Nordeide JT (1998) Coastal cod and north-east Arctic codDo they mingle at the spawning grounds in Lofoten? Sarsia 83:373-379

Nordeide JT, Folstad I (2000) Is cod lekking or a promiscuous group spawner? Fish Fish 1:90-93

Nordeide JT, Kjellsby E (1999) Sound from spawning cod at their spawning grounds. ICES J Mar Sci 56:326-332

Nordeide JT, Pettersen IH (1998) Haemoglobin frequencies and vertebral numbers of cod (Gadus morhua L.) off northern Norway-test of a population structure hypothesis. ICES J Mar Sci 55:134-140

O'Leary DB, Coughlan J, Dillane E, McCarthy TV, Cross TF (2007) Microsatellite variation in cod Gadus morhua throughout its geographic range. J Fish Biol 70:310-335

> Otterå H, Jørstad KE, Svåsand T, Kristiansen TS (1999) Migration patterns and recapture rates of North-East Arctic and Norwegian coastal cod reared and released under similar conditions. J Fish Biol 54:213-217

> Otterå H, Agnalt AL, Jørstad KE (2006) Differences in spawning time of captive Atlantic cod from four regions of Norway, kept under identical conditions. ICES J Mar Sci 63: 216-223

Otterlei E, Nyhammer G, Folkvord A, Stefansson SO (1999) Temperature- and size-dependent growth of larval and early juvenile Atlantic cod (Gadus morhua): a comparative study of Norwegian coastal cod and northeast Arctic cod. Can J Fish Aquat Sci 56:2099-2111

> Otterlei E, Folkvord A, Nyhammer G (2002) Temperature dependent otolith growth of larval and early juvenile Atlantic cod (Gadus morhua). ICES J Mar Sci 59:401-410

Palsbøll PJ, Berube M, Allendorf FW (2007) Identification of management units using population genetic data. Trends Ecol Evol 22:11-16

Palumbi SR (1994) Genetic divergence, reproductive isolation, and marine speciation. Annu Rev Ecol Syst 25: $547-572$

Pampoulie C, Stefansson MÖ, Jörundsdottir TD, Danilowicz BS, Danielsdottir AK (2008) Recolonization history and large-scale dispersal in the open sea: the case study of the North Atlantic cod, Gadus morhua L. Biol J Linn Soc 94: 315-329

Pedersen T (1984) Variation of peak spawning of Arcto-Norwegian cod (Gadus morhua L.) during the time period 1929-1982 based on indices estimated from fishery statistics. In: Dahl E, Danielsen DS, Moksness E, Solemdal P (eds) The propagation of cod (Gadus morhua L). Oluf Rasmussen A/S, Skien, p 301-316

Petersen MF, Steffensen JF (2003) Preferred temperature of juvenile Atlantic cod Gadus morhua with different haemoglobin genotypes at normoxia and moderate hypoxia. J Exp Biol 206:359-364

Pogson GH (2001) Nucleotide polymorphism and natural selection at the pantophysin (Pan I) locus in the Atlantic cod, Gadus morhua (L.). Genetics 157:317-330

Pogson GH, Fevolden SE (2003) Natural selection and the genetic differentiation of coastal and Arctic populations of the Atlantic cod in northern Norway: a test involving nucleotide sequence variation at the pantophysin (Pan I) locus. Mol Ecol 12:63-74

> Pogson GH, Mesa KA (2004) Positive Darwinian selection at the pantophysin (Pan I) locus in marine gadid fishes. Mol Biol Evol 21:65-75

> Pogson GH, Mesa KA, Boutilier RG (1995) Genetic population-structure and gene flow in the Atlantic cod Gadusmorhua-a comparison of allozyme and nuclear RFLP loci. Genetics 139:375-385

Reisegg J, Jørstad KE (1984) Stock structure of cod in the Møre area. In: Dahl E, Danielssen DS, Moksness E, Solemdal P (eds) The propagation of cod Gadus morhua L, Book 2. Oluf Rasmussen AS, Skien, p 609-624

Rollefsen G (1933) The otoliths of the cod-preliminary report. Fiskeridir Skr Ser Havunders 4:1-18

Rollefsen G (1934a) The cod otolith as a guide to race, sexual 
development and mortality. Rapp P-V Reùn Cons Int Explor Mer 88:1-5

Rollefsen G (1934b) Torsken og Fiskehavet 1933. Skreiens alder. Fiskeridir Skr Ser Havunders 4:12-15

Rollefsen G (1954) Observations on the cod and cod fisheries of Lofoten. Rapp P-V Reùn Cons Int Explor Mer 136:40-47

Rowe S, Hutchings JA (2003) Mating systems and the conservation of commercially exploited marine fish. Trends Ecol Evol 18:567-572

Rowe S, Hutchings JA, Skjæraasen JE, Bezanson L (2008) Morphological and behavioural correlates of reproductive success in Atlantic cod Gadus morhua. Mar Ecol Prog Ser 354:257-265

Ryman N, Utter F, Laikre L (1995) Protection of intraspecific biodiversity of exploited fishes. Rev Fish Biol Fish 5: 417-446

Salanti G, Amountza G, Ntzani EE, Ioannidis JP (2005) HardyWeinberg equilibrium in genetic association studies: an empirical evaluation of reporting, deviations, and power. Eur J Hum Genet 13:840-848

Salvanes AGV, Skjaeraasen JE, Nilsen T (2004) Sub-populations of coastal cod with different behaviour and life-history strategies. Mar Ecol Prog Ser 267:241-251

Sarvas TH, Fevolden SE (2005a) Pantophysin (Pan I) locus divergence between inshore v. offshore and northern v. southern populations of Atlantic cod in the northeast Atlantic. J Fish Biol 67:444-469

Sarvas TH, Fevolden SE (2005b) The scnDNA locus Pan I reveals concurrent presence of different populations of Atlantic cod (Gadus morhua L.) within a single fjord. Fish Res 76:307-316

Schmidt J (1930) Raceundersøgelser. X. Den atlantiske torsk (Gadus callarias L.) og dens lokale racer. C R Trav Lab Carlsberg 18:1-72 (in Danish)

Skarstein TH, Westgaard JI, Fevolden EE (2007) Comparing microsatellite variation in north-east Atlantic cod (Gadus morhua L.) to genetic structuring as revealed by the pantophysin (Pan I) locus. J Fish Biol 70(Suppl C):271-290

Skjæraasen JE, Rowe S, Hutchings JA (2006) Sexual dimorphism in pelvic fin length of Atlantic cod. Can J Zool 84: 865-870

Smith PJ, Birley AJ, Jamieson A, Bishop CA (1989) Mitochondrial DNA in the Atlantic cod, Gadus morhua: lack of genetic divergence between eastern and western populations. J Fish Biol 34:369-373

Stransky C, Baumann H, Fevolden SE, Harbitz A and others (2008) Separation of Norwegian coastal cod and Northeast Arctic cod by outer otolith shape analysis. Fish Res 90: $26-35$

Sundby S (2000) Recruitment of Atlantic cod stocks in relation to temperature and advection of copepod populations. Sarsia 85:277-298

Sundby S, Nakken O (2008) Spatial shifts in spawning habitats of Arcto-Norwegian cod related to multidecadal climate oscillations and climate change. ICES J Mar Sci 65:

Editorial responsibility: Inna Sokolova, Charlotte, North Carolina, USA
953-962

Suthers IM, van der Meeren T, Jorstad KE (1999) Growth histories derived from otolith microstructure of three Norwegian cod stocks co-reared in mesocosms; effect of initial size and prey size changes. ICES J Mar Sci 56:658-672

Svåsand T, Jørstad KE, Otterå H, Kjesbu OS (1996) Differences in growth performance between Arcto-Norwegian and Norwegian coastal cod reared under identical conditions. J Fish Biol 49:108-119

Svendsen JI, Alexanderson H, Astakhov VI, Demidov I and others (2004) Late Quaternary ice-sheet history of northern Europe. Quat Sci Rev 23:1229-1271

> Tåning ÅV (1952) Experimental study of meristic characters in fishes. Biol Rev Camb Philos Soc 27:169-193

Templeman W (1981) Vertebral numbers in Atlantic cod, Gadus morhua, of the Newfoundland and adjacent areas, 1947-71, and their use for delineating cod stocks. J Northwest Atl Fish Sci 2:21-45

Templeman W (1983) Stock discrimination in marine fishes. NAFO Sci Coun Stud 6:57-62

van der Meeren T, Jørstad KE (2001) Growth and survival of Arcto-Norwegian and Norwegian coastal cod larvae (Gadus morhua L.) reared together in mesocosms under different light regimes. Aquacult Res 32:549-563

Van der Meeren T, Jørstad KE, Solemdal P, Kjesbu OS (1994) Growth and survival of cod larvae (Gadus morhua L.): comparative enclosure studies of Northeast Arctic cod and coastal cod from western Norway. ICES Mar Sci Symp 198:633-645

Vollset KW, Seljeset O, Fiksen O, Folkvord A (2009) A common garden experiment with larval Northeast Arctic and Norwegian coastal cod cohorts in replicated mesocosms. Deep-Sea Res 56:1984-1991

- Wallace B (1958) The comparison of observed and calculated zygotic distributions. Evolution 12:113-115

- Waples RS (1998) Separating the wheat from the chaff: patterns of genetic differentiation in high gene flow species. J Hered 89:438-450

> Waples RS, Gaggiotti O (2006) What is a population? An empirical evaluation of some genetic methods for identifying the number of gene pools and their degree of connectivity. Mol Ecol 15:1419-1439

Wennevik V, Jørstad K, Dahle G, Fevolden SE (2008) Mixed stock analysis and the power of different classes of molecular markers in discriminating coastal and oceanic Atlantic cod (Gadus morhua L.) on the Lofoten spawning grounds, northern Norway. Hydrobiologia 606:7-25

Wentzel-Larsen T, Nordeide JT (2001) Testing for homogeneity in sampling from sympatric non-interbreeding populations based on gene frequencies: the case of stationary and migratory cod. Sarsia 86:229-235

> Westgaard JI, Fevolden EE (2007) Atlantic cod (Gadus morhua L.) in inner and outer coastal zones of northern Norway display divergent genetic signature at non-neutral loci. Fish Res 85:306-315

Submitted: November 24, 2011; Accepted: May 25, 2011

Proofs received from author(s): August 9, 2011 